\author{
Dr. sc. Tone Jagodic \\ Olympic Committee of Slovenia, Ljubljana \\ Dr. sc. Zlatko Mateša \\ Zagreb School of Economics and Management, Zagreb
}

\title{
BASIC ELEMENTS OF A SPONSORSHIP CONTRACT IN SPORT
}

\author{
UDK: 796. 078 \\ Primljeno: 10. 12. 2017. \\ Izvorni znastveni rad
}

Sponsorship represents very important source of finances for many sports organizations. The aim of the article is to analyze structural elements of sponsorship contract and to propose a proper definition of a sponsorship contract, while leaning on the many sources of comparative law. The review of foreign legislation shows that not one country has yet legally enacted the sponsorship contract. Some legislation regulate sponsorship in an indirect way using common rules of contractual law or some elements of other contracts, which are already well known and regulated by legal systems. In determining the validity of the arguments cited by the individual authors in the literature our aim is to come to some conclusions which have been summarized in following parts of this article. It seems that the Code of sponsorship of the International Chambers of Commerce (ICC) gives the real foundation which can be useful for different sport organizations. Following the ICC International Code on Sponsorship, the definition of a sponsorship agreement "is any commercial agreement by which a sponsor, for the mutual benefit of the sponsor and a sponsored party, contractually provides financing or other support in order to establish an association between the sponsor's image, brands or products and a sponsorship property in return for the rights to promote this association and/or for the granting of certain agreed direct or indirect benefits." Brand of the sponsor, identification with the property of the sponsored subject, commercial agreement, right to promote and mutual benefit are the vital components of a sponsorship contract which are contained in the ICC definition. We also believe that in the future, this definition could lead to the right definition for a possible codification of a sponsorship contract on the national level. At the same time it is important to mention the special characteristic of the specific value of the sponsored subject contained in a sponsorship contract. From the angle of the sponsor this value can be compared with a special and characteristic element of the sponsored subject which brings to the sponsor a very precious value /"pretium affectionis"/ and is consequently extremely important in a rational economic decision of a sponsor to sign a sponsorship contract. Taking into account that all these elements represent the "causa" of a sponsorship contract the position of the sponsor could be defined as the tendency to identify with the value of the sponsored party, with the aim to further manifest itself by promoting these links, both of which lead to the goal of a sponsor to raise or improve its image in public or in a society. The essential challenge of the sponsor is to manage to change the opportunity into the advantage given in the contract relationship. Opportunities should be taken from the challenges which are given to the sponsor and this represents the original motive of the sponsor to sign a sponsorship contract.

Key words: sponsorship, agreement, mutual benefit, definition, pretium affectionis, specific value 
Dr. sc. Tone Jagodic i dr. sc. Zlatko Mateša: Basic elements of a sponsorship contract in sport Zbornik radova Pravnog fakulteta u Splitu, god. 55, 2/2018., str. 275.- 287.

\section{INTRODUCTION}

Sport has become one of the fastest growing industries in modern developed countries. An important part of the business of sports is sports marketing which revolves around the understanding of a consumer's behaviour and the motivating of target markets to purchase goods and services. Sports marketing is needed because it helps sports organizations to get the financial resource which is needed for their survival. Nearly every professional team or athlete participates in some kind of marketing or promotion. If we know that sponsoring is, along with the revenues from broadcasting rights, the most important marketing tool for sport organizations, then it is logical that the specialization of sponsorship has already made steps forward. On the other hand, sponsorship has become a subject of scientific examinations in different areas.

Taking into account the fact that the funds come from private sector and that more and more sporting entities depend on this source, it is interesting to figure out which the key constituent elements of the sponsorship are. The relationships in sponsorship shall be governed by a sponsorship contract which means that it makes sense to analyze the content of this sponsorship contract, facing a growing number of athletes and other sports subjects which are involved in the relation of sponsorship.

Having in mind this situation, it is from a legal point of view, a particular challenge, how to identify the sponsorship relationship in a way to determine (1) what the key or essential elements of the contractual relationship are, (2) what makes this contract so much inherent and different from the other contract types, (3), which segments of the other contacts that already exist are applicable, and (4) which legal institutes are appropriate for the interpretation of the different solutions offered by the sponsoring contract. Taking into account the fact that it is an inominative contract, which is not regulated in the legislation it would be important to identify the key elements that the definition of a sponsorship contract consists of. Some of conclusion are also analyzed in the text "Structural elemets and definition of a sponsorship contract in sport. The aim of this article is to analyze structural elements of sponsorship contract and to propose a proper definition of a sponsorship contract, while leaning on the many sources of comparative law. The review of foreign legislation shows that not one country has yet legally enacted the sponsorship contract. Some legislation regulate sponsorship in an indirect way using common rules of contractual law or some elements of other contracts, which are already well known and regulated by legal systems. In determining the validity of the arguments cited by the individual authors in the literature our aim is to come to some conclusions which have been summarized in following parts of this article. 


\section{CATEGORIES OF SPONSORSHIP}

There are many approaches with specific criteria how to divide sponsorship into different categories of sponsorship. Some claim that sponsorship depends on the type of sponsors, the characteristic type of the service provided for sponsors, the category of sport activity (sport for all, competition sport and elite, top sport sponsorships), the aim and the direction of sponsorship and many others. Capurro divides sponsorship into 3 categories. Sponsorship of

- $\quad$ legal entities (corporate sponsorship),

- events

- an individual athlete.

The most common subject of the corporate sponsorship on the side of a sponsored party is a legal entity of private law such as a sport club, an association, a federation, a National Olympic Committee, a national sports confederation, a foundation, a pool, an agency or some other private legal entity. It is interesting that among the sponsored parties in non sports sectors we also find categories of a public legal entity such as a public agency, a museum, an opera house, a school, a hospital and others.

Considering the sponsorship contract where an individual athlete is involved as a sponsored party it is worth to mention the specific of endorsement as one of the most popular relationship of athletes especially in the USA.

\section{ENDORSEMENT}

It is questionable whether endorsement is a type of sponsorship contract of an individual athlete or it represents its own type of contract. There are many differences between both types of the contracts of an individual personality, especially in the USA, and that is why most of the American literature deals with both types separately. In theory it is not clear if endorsement is only one type of sponsorship of an individual athlete or it is a special legal relationship of an athlete with a commercial partner. In Europe the distinction is not as clear as endorsement has not been developed as much as in the USA.

There are different definitions of endorsement agreements. An endorsement is a promotional and marketing tool that takes advantage of a reputation of personality. It is the personal recommendation by a personality of a product or service. Endorsement is the promotion of a company's product by means of personal recommendation of an individual who is sufficiently well known and respected that he can influence the purchasing pattern of sections of the consumer public.

In a sense, a personality sponsors the company's product, and is paid for doing so. It is a much simpler commercial agreement than the sponsorship, and is a means whereby that personality can extend his/her own programme of self 
promotion to increase his/her earning capacity, and to maintain a profile in the public eye. Endorsement is a form of specialised advertising by the manufacturer of the endorsed product. This form of sponsorship has been introduced and developed in the USA, but is quickly getting its space in Europe. Schaaf considers endorsement as a sustainable type of sponsorship.

Society chooses to purchase products that are known, guaranteed and convenient. Companies believe that society is more likely to purchase a certain product if an athlete says it is appropriate or beneficial. A product or a brand may be weak, but an athlete's reputation gives it credibility. This allows a certain product to be seen regularly and allows the viewer to get to know the athlete and the companies that are endorsing them. An endorsement of a product by a celebrity is very influential on the public's opinion of the product. Numerous athletes have become "celebrities" due to the increase in endorsements and the companies that have sponsored them.

The relationship between sponsorship of an individual athlete and endorsement is open to discussion. Even if we do not go deeply into endorsement we can find out some differences and specialities of both arrangements. The most important characteristic of endorsement is the promotion of a product, service, a name or some other element of a company (sponsor). On the other hand, sponsorship is more "sporty" oriented as a sponsor tries to identify his image with successful sporting results of his sponsored subject. If an athlete gets royalty for his commercial efforts for the benefit of his client, a sponsor often gives prizes to his sponsored athlete for outstanding sports achievements. There are also more differences of both types of relationship of an athlete with a commercial partner but, on the other hand, the basic positions of both arrangements are similar. It is therefore justified to claim that endorsement is only a very specific type of an individual sponsorship contract

\section{DEFINITION OF A SPONSORSHIP CONTRACT}

There are many different legal definitions of a sponsorship contract. It seems that the Code of sponsorship of the International Chambers of Commerce (ICC) gives the real foundation which can be useful for different sport organizations. Following the ICC International Code on Sponsorship, the definition of a sponsorship agreement "is any commercial agreement by which a sponsor, for the mutual benefit of the sponsor and a sponsored party, contractually provides financing or other support in order to establish an association between the sponsor's image, brands or products and a sponsorship property in return for the rights to promote this association and/ or for the granting of certain agreed direct or indirect benefits." After analyzing different parts of the above definition, we can put the most important elements into the following scheme: 


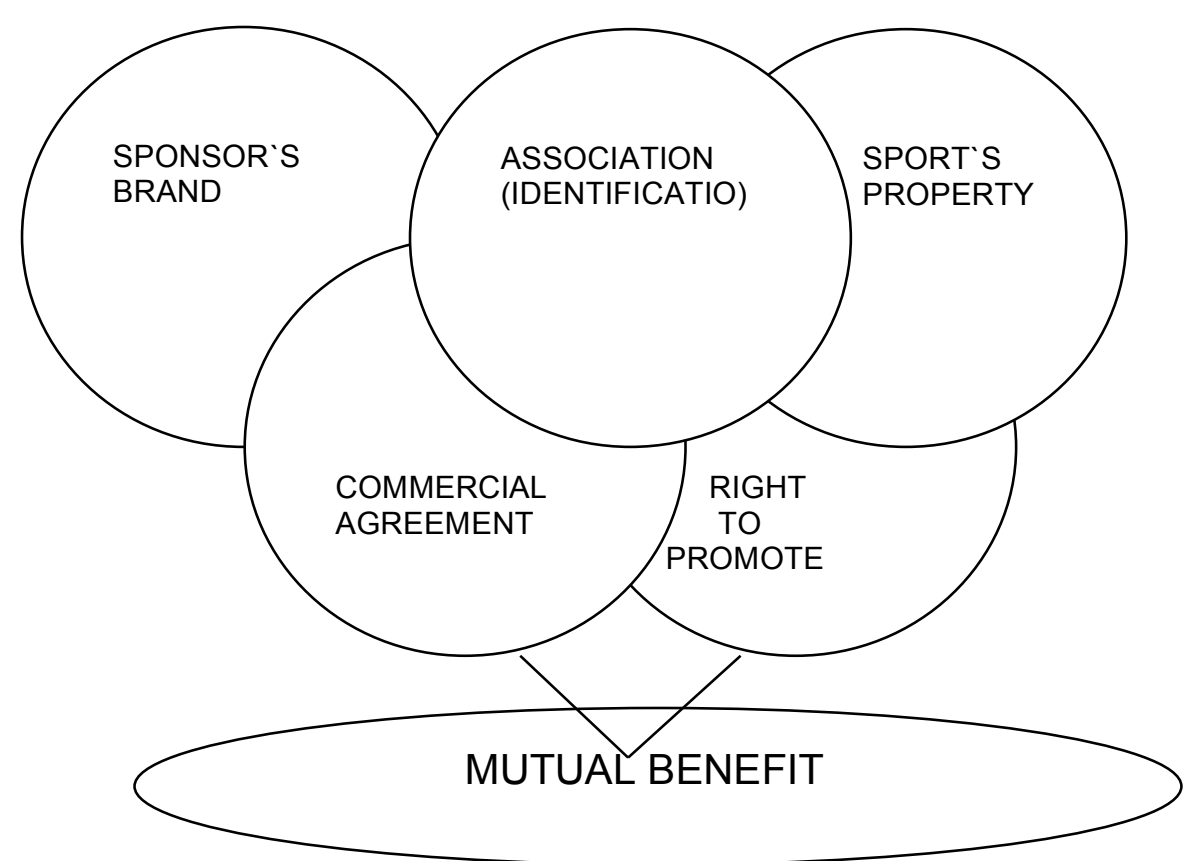

Analyzing those elements it can be underlined that there are three elements that are specific for sponsorship and different from the elements of other known legal contracts:

1. The basic connection represents the association between a sports property and a sponsor brand as a tool how to transfer the image of a sport subject to a sponsor. It is, of course, necessary to establish a commercial agreement with the possibility to promote that connection (the identification between the value of a sports subject and a sponsor's entity) in the awareness of the public.

2. The right to promote the identification between a sponsored party and a sponsor is tightly linked to media exposure, as it provides public identification of the sponsorship subjects' relationship. The promotion of sponsorship in media by a sponsor can increase the value of the sponsorship property and that is also the main aim and interest of both parties. Both parties try to achieve the public awareness of a close connection between them.

3. Both parties look forward for common - mutual benefit. Compared with some other contracts, it is very unique that common (mutual) interest of both parties is so essential. The common aim of both parties is to increase the value of the sponsorship property and they work together to achieve this common task. 
Dr. sc. Tone Jagodic i dr. sc. Zlatko Mateša: Basic elements of a sponsorship contract in sport Zbornik radova Pravnog fakulteta u Splitu, god. 55, 2/2018., str. 275.- 287.

There are different characteristics of a sponsorship contract. A very special element of sponsorship is the sponsorship property which is unique and represents causa ${ }^{1}$ of a sponsorship contract. The substance of the contract is strictly dependant on the sponsorship property. The main aim is the transfer of that sponsored party intellectual right (image) to the sponsor and the right to the use of the name of the sponsored party. The rights coming out of the sponsorship property and which are transferred to the sponsor, are the most typical and significant characteristics of a sponsorship agreement. The aim of the sponsor is to take the advantage of the goodwill associated with the particular sporting property that is being sponsored. ${ }^{2}$

Regardless of the fact that the above graphic illustration might seem too simple we strongly believe that it covers all of the key elements of a sponsorship contract, which anybody dealing with sponsorship should be familiar with.

\section{ELEMENTS OF A SPONSORSHIP CONTRACT}

It is well known that a sponsorship contract has not been codified yet. It seems that the nature of the relationship is still "moving forward" and it would not be appropriate to stop the development of this modern contract with formal codification. ${ }^{3}$ Apart from that it is also obvious that sponsorship contracts are very common in practice and it is therefore recommendable to find out basic legal principles which are suitable for the interpretation of the relationship. Being a modern contract of autonomous commercial law, it should be noticed that for it all basic principles of commercial civil law should apply; the principle of autonomy, equal rights of parties, conscientiousness and honesty, prohibition of misuse of the rights, prohibition of making harm, commitment to fulfil obligations, solidarity in collaboration, peaceful resolving of disputes and some others. A sponsorship contract is a contract of two or more parties, an obligatory, consensual, ${ }^{4}$ non-formal, sinalagmatic ${ }^{5}$ and commutative ${ }^{6}$ civil law contract. Among common characteristics of one of the contracts of autonomous law, it is functional heterogeneous with practical economical meaning, at some lower levels standardized and has a normative nature. ${ }^{7}$

1 Causality - the relationship between something that happens and the reason for it happening; the principle that nothning can happen without a cause

Verow, Lawrence, McCormick, (1999), Sport, Business and the Law, Jordans, p. 204,

3 Grilc, (1996) Moderni tipi pogodb avtonomnega gospodarskega prava, (Modern types of the contracts of autonomous commercial law, Gospodarski vestnik, Ljubljana, p. 88,

4 Consensual - which people in general agree with; agreement

5 Could also be described as a kind of reciprocal agreement ; a situation in which two subjects provide advantages and obligations to each other at the same time

6 Commutative - giving the same result whatever the order in which the quantities are shown

7 Jagodic, (2007), Pravne značilnosti sponzorskih pogodb v olimpijskem gibanju, (Legal characteristics of sponsorship contracts in Olympic movement), Pravna fakulteta v Ljubljani, p. 257-258, 
Apart from those principles, some other specific legal elements should be considered when examining a sponsorship contract. Particular elements are not poured into a harmonious mixed contract and the relations of the parties cannot be subsumed into one of the established, known and already codified types of contracts. ${ }^{8}$ Many of them are very complex and beside essential structural elements contain many additional and subsidiary activities with the aim to optimize the effects of the main component of the contract. After analyzing some $\mathrm{NOC}^{9}$ sponsorship contracts it could be concluded that the main object of sponsorship is the transfer of the sponsorship property of the sponsored subject into the sphere of the sponsor which is usually combined with the right to use the name of the sponsored party. Most of the contracts include the exclusivity clause, the obligation of the sponsored party for the legal protection, common interest of both parties with the aim to enlarge the value of the object of the contract, clause of confidence, the wish to achieve a longterm relationship, common care of successful public communication and the wish to renew the expiring contract.

Very typical characteristics of the modus of accomplishing the contract is the media involvement tightly connected with public appearances of both parties with the particular aim of the sponsor of the identification and recognition of their relationship. ${ }^{10}$ One of the most specific and typical elements of sponsorship is the active role and position of the sponsor with its task to take advantage of the sponsorship property using the rights acquired from the sponsored party. It seems that the most specific and typical element of sponsorship is the manner of the identification between the entity of a sponsor and the value of a sponsored subject (sponsorship property). ${ }^{11}$

Most of the contracts are connected with some obligations of other relationships, especially those of a sponsored party. In the world of commercial top sport, it is normal to have different relationships of the athlete, his club, federation, NOC with their own sponsors and therefore it is of the utmost importance to balance all those different interests.

\subsection{Substantive legal elements}

If we try to make the hypothesis that the recognition of a special and specific sponsorship value of the sponsored subject by the sponsor is the preliminary condition of the sponsorship contract, we have to take into account that this specific value has emerged out of sport, and that it attracts the world of business very much. This specific value of a sport subject is hard to find elsewhere and that is why it is so attractive for a commercial subject. The commercialization of sport has introduced

8 Kranjc, (2006), Gospodarsko pogodbeno pravo, GV Založba, Ljubljana, p. 233,

9 NOC - abbreviation for a National Olympic Committee,

10 Jagodic, (2008), Sponzorstvo v športu, (Sponsorship in sport), Chapter in the book Šport in pravo (Sport and Law), GV Založba, p. 208,

11 Vieweg,(1994), Sponsoring und Sportrecht, Sport nr. 1-2/94, p. 6 
certain new values from the world of sport and launched them to the public by modern ways of communication.

The foundations of sponsorship in legal sense are

- personality rights of the athletes, ${ }^{12}$

- intellectual rights of sport organizations and

- special "sui generis" ${ }^{13}$ rights of the organizer of a sport competition. ${ }^{14}$

A sponsor decides for sponsorship trying to use a sponsored subject with specific attributes to achieve certain positive effects. The main object of sponsorship is the sponsorship property, which gives the sponsor a specific, original and individual approach to the commercial market and to target particular costumers, which is quite different from other conventional means of advertisement or propaganda. ${ }^{15}$ Sponsors invest huge amounts of money into sponsorship as they believe that they could make a good investment bringing them certain commercial effects.

The sponsorship property is materialized in different shapes and formations. Its speciality is a specific distinction which gives it another character, much different from other similar values. This particularity involves a touch of a class, extraordinariness, attraction, extreme popularity and fame and reputation, maybe even a kind of a genius. It is the perception of this value system by the public and the environment in which we live that is the final target of the sponsors. The exceptional value of sponsorship which makes a sponsor ready to make a contract is made by the public. Celebrities are famous for a certain reason and that is why they are attractive for sponsors. The same applies to famous sports teams, clubs, organizations or sport competitions which constitute a certain precious brand which are sought by sponsors. The meaning of the brand of the Olympic Games is much more than just a picture of five rings because people recognize this mark as a symbol of an exceptional international sport competition, with the best athletes, sport heroes, Olympic legends and tradition, the Olympic Idea and philosophy, what makes it so popular all around the world. ${ }^{16}$

\section{Legal characteristics of a sponsorship contract}

Most sponsorship agreements are long term, strictly confidential and strive for a successful public relationship. Sponsorship contracts are complex as they

12 Levovnik, (2008), Personal rights of the athletes (Osebnostne pravice športnikov), Chapter in the book Šport in pravo (Sport and Law), GV Založba, p. 147,

13 Sui generis - Latin expression for non-typical, very specific, special type, sui generis contracts ...

14 Jagodic, (2008), Sponzorstvo v športu, (Sponsorship in sport), Chapter in the book Šport in pravo, (Sport and Law), GV Založba, p. 205,

15 Jagodic, (2008), Sponzorstvo v športu, (Sponsorship in sport), Chapter in the book Šport in pravo (Sport and Law), GV Založba, p. 206,

16 Jagodic (2011), Legal aspects of international event sponsorship, Chapter in Handbook on International Sports Law, Edward Elgar Publishing 1td, Cheltenham, U.K., Northampton USA, p. 530, 
consist of many different activities which are supposed to assist the principal core of the contract with the aim to optimally emphasize the commercial benefits of the agreement. Practical economic ratio and functional heterogeneity are the vital elements as we can see in some other modern inominative contracts. ${ }^{17}$

Distinction should be made between sponsors and suppliers. Many sponsorship contracts have more than 2 parties. A lot of contracts with 2 parties are connected with other contracts and consist of some obligations of the subjects who are not contractual parties (athletes have to fulfill some obligations on behalf of a sport organization). A sponsor is entitled to certain rights of a sponsored party, but it is up to its determination and decision to activate those rights in a way that it would bring the expected benefits to it. The evaluation of the contract is vital; inactive role of sponsor exploitation of its rights should not be relevant for the value of the contract. The execution of sponsor's rights is important and depends on the sponsor's ability to exploit its position. The obligations of a sponsored party could be split in 3 directions:

- $\operatorname{cession}^{18}$ of its rights to a sponsor,

- fulfillment of different services,

- efforts to transfer its image to a sponsor.

\subsection{Exclusivity as a special and specific element of a sponsorship contract}

Exclusivity is becoming a very important element of a sponsorship relationship. In these cases, the sponsor's right of exclusivity represents the most important element from the sponsor's side. The exclusivity of a sponsor represents an essential element of the contract as it means the priority for the sponsor trying to create a distinction towards its business competitor. There is a clear distinction between the exclusivity of a sponsor in a sponsorship agreement and a contract of selling of the TV rights. Both rights represent two different groups of rights coming from different rights of sponsored subjects. Practical reasons demand an adjustment between the interest of sponsors of a sport event and the sponsors of the TV. ${ }^{19}$ Both parties should respect different limitations regarding the substance of the contract; a sponsor must particularly take care of legal restrictions, imposed by law. A clear distinction should be made between the organizer of a sport event and an athlete / team/ competing at that event, as they both have their own sponsors with different interests. $^{20}$

17 Grilc, (1996), Moderni tipi pogodb avtonomnega gospodarskega prava, (Modern types of the contracts of autonomous commercial law), Gospodarski vestnik, Ljubljana, p. 105-106,

18 Cession - assignment, transfer of the rights

19 Stupp, (1993), Broadcasting, International Sports sponsorship, Sports Marketing Europe, The Legal and Tax aspects, Kluver Law and Taxation Publishers, Deventer, Boston, p. 418

20 Verow, Lawrence, McCormick, (1999), Sport, Business and the Law, Jordans, p. 213, 


\section{LEGAL NATURE OF A SPONSORSHIP CONTRACT}

The relations of sponsorship are hard to subsume within one of the known types of contracts, every contract must be carefully analyzed. They consist of different rights and obligations which are typical for some other contracts. It is an inominative contract and it is not legally codificated. As a special contract, a non typical (non formulaic) model of a contract, each contract is a specific and individual one. There are also some other modern contracts (like franchising) where the essence of the contract is composed by more relationships which are connected together. ${ }^{21}$ Very similar conclusions were also found for the contract of selling TV rights of sports organizers and sports organizations. ${ }^{22}$ Only some sponsorship agreements can be subordinated or compared with other nominative ${ }^{23}$ contracts.

A licensing agreement is applicable for some sponsorship contracts which are based on intellectual property. We can find out that sponsorship is a new legal instrument which consists of more integrated and connected relations; it is not a "compound" 24 contract. In some cases, it can be regarded as a "mixed" contract if the provisions match with the regulations of some known nominative contract. ${ }^{25} \mathrm{In}$ its essence it is a sui generis contract with typical characteristics and structure so that it is possible to make a distinction between other contracts. ${ }^{26}$

Apart from sponsorship of sports organizations, sponsorship of individual athletes has another specific nature as they are mostly not based on intellectual industrial rights but rely more on personal property rights.

After analyzing the elements of some of the NOC sponsorship contracts ${ }^{27}$ we can find out some interesting facts regarding the legal nature of this contract. Like some other inominative modern contracts, a sponsorship agreement is a special sui generis contract. Some sponsorship contracts have similarities with licensing as the main object of the contract is an intellectual right. The TOP and the NOC contracts are based on the value of the Olympic rings. The image of the Olympic rings as a world famous trade mark makes the essence of the contract in a way which looks as if it were a licensing agreement. A closer look into the structure of the

21 Grilc, (1990), Pogodba o franchisingu, (Franchising contract), Pravna fakulteta Ljubljana, p 64,

22 Bergant - Rakočevič (2001), Pravna narava televizijskih pravic na športni prireditvi, (Legal nature of TV rights of sports competition), Pravna fakulteta v Ljubljani, p. 101,

23 Nominative contracts - in most cases already regulated contracts with names that are well established

24 A contract consisting of two or more separate contracts combined together

25 Netzle, (1988), Sponsoring von Sportsverbunden, Vertrags, personlichkeits und vereinsrechliche Aspekte des Sports Sponsoring, Schulthess Polygraphisher Verlag, Zurich, p. 32

26 The same conclusion see also Hauser, (1991), Der Sponsoring - Vertrag im schweitzeritchen Recht, Schulthess Polygraphisher Verlag, Zurich, p. 283

27 NOCs of Austria, Germany, Great Britain and Slovenia 
$\mathrm{TOP}^{28}$ contract proves the thesis of making a distinction between this sponsorship agreement and an ordinary licensing contract.

The basic difference lies in the way how the object of the contract is used. As a licensee is trying to use the trade mark itself, the sponsor is trying to connect the trade mark with his own name, brand or product. It is very common that sponsors use the Olympic rings together with their own brand names and logos (a composite logo) trying to raise the image and value of their own brand. Beside the elements which are very close to the elements of a licensing agreement, the TOP agreement gives a sponsor many other rights which are not common for an ordinary licensing agreement. Some of the elements (ticketing, hospitality, and merchandising) are also structural parts of a sponsorship agreement. Some elements of other contracts can be found in certain sponsorship agreements, such as a sales agreement, leasing contract, a labour contract, selling of the TV rights, joint venture ${ }^{29}$ and some others. The most important fact is that the sole right to use the brand name is only one part of the essence of the contract, far more important is the way how successfully a sponsor uses this intellectual property. One of the most specific and relevant elements is the exclusivity of sponsors. A sponsorship contract has developed exclusivity as a special element of distinction between the sponsors which are recognized by the public as a close link with the sponsored subject and another commercial competitor in its brand. Ambush marketing is a very specific attempt to diminish the value of sponsorship and NOCs have been developing special ways and legal means of how to protect and defend sponsorship property from it.

\section{CONCLUSIONS}

Having in mind the abovementioned elements referred to especially in part 4 of this article, we consider that the key components of a sponsorship contract are contained in the definition confirmed by the ICC. At the same time it is important to mention the special characteristic of the specific value of the sponsored subject contained in a sponsorship contract. From the angle of the sponsor this value can be compared with a special and characteristic element of the sponsored subject which brings to the sponsor a very precious value /"pretium affectionis"/ and is consequently extremely important in a rational economic decision of a sponsor to sign a sponsorship contract.

We would like to underline that those 6 elements grouped in a specific relationship are the most typical for the sponsorship contract. Regardless of the fact that sponsorship is not only the characteristic of the Olympic Movement but we believe that all the mentioned 6 elements, which are arranged in the Olympic circle on a platter, represent the key elements of the sponsorship contracts for general use.

${ }_{28}$ TOP; abbreviation for The Olympic Progamme, name of the Marketing programme of the International Olympic Committee,

29 Business contract that is begun by two or more subjects which remain separate organizations 
Dr. sc. Tone Jagodic i dr. sc. Zlatko Mateša: Basic elements of a sponsorship contract in sport Zbornik radova Pravnog fakulteta u Splitu, god. 55, 2/2018., str. 275.- 287.

The elements described above follow the definition of a sponsorship contract issued by the ICC. All the elements that have been described in the graphic way (chapter 4 of the article) in the form of a certain interconnection, express my belief that this definition represents the structure that covers all the typical elements of a sponsorship contract. We also believe that in the future, this definition could lead to the right definition for a possible codification of a sponsorship contract.

Taking into account that all these elements represent the "causa" of a sponsorship contract the position of the sponsor could be defined as the tendency to identify with the value of the sponsored party, with the aim to further manifest itself by promoting these links, both of which lead to the goal of a sponsor to raise or improve its image in public or in a society. The essential challenge of the sponsor is to manage to change the opportunity into the advantage given in the contract relationship. Opportunities should be taken from the challenges which are given to the sponsor and this represents the original motive of the sponsor to sign a sponsorship contract.

\section{LIST OF REFERENCES}

Bergant - Rakočevič Vesna (2001), Pravna narava televizijskih pravic na športni prireditvi, (Legal nature of TV rights of sports competition), Pravna fakulteta v Ljubljani,

Capurro Roberto, (1993) Sports Marketing Europe, The Legal and Tax Aspects, Kluver Law and Taxation Publishers, Deventer, Boston

Grilc Peter, (1996) Moderni tipi pogodb avtonomnega gospodarskega prava, (Modern types of the contracts of autonomous commercial law, Gospodarski vestnik, Ljubljana,

Grilc Peter, (1990), Pogodba o franchisingu, (Franchising contract), Pravna fakulteta Ljubljana

Hauser Thomas, (1991), Der Sponsoring - Vertrag im schweitzeritchen Recht, Schulthess Polygraphisher Verlag, Zurich,

Jagodic Tone, (2007), Pravne značilnosti sponzorskih pogodb v olimpijskem gibanju, (Legal characteristics of sponsorship contracts in Olympic movement), Pravna fakulteta $v$ Ljubljani

Jagodic Tone (2011) »Legal aspects of international event sponsorship«, Chapter in Handbook on International Sports Law, Edward Elgar Publishing ltd, Cheltenham, U.K., Northampton USA,

Jagodic Tone, (2008), Sponzorstvo v športu, (Sponsorship in sport), Chapter in the book Šport in pravo (Sport and Law), GV Založba,

Jagodic Tone, Bednarik Jakob (2016); Structural elemets and definition of a sponsorship contract in sport, Kineosologija Slovenica, nr. 22, 1, p. 5-15, 
Kranjc Vesna, (2006), Gospodarsko pogodbeno pravo, GV Založba, Ljubljana,

Levovnik Jure, (2008), Personal rights of the athletes (Osebnostne pravice športnikov), Chapter in the book Šport in pravo (Sport and Law), GV Založba,

Netzle Stephan, (1988), Sponsoring von Sportsverbunden, Vertrags, personlichkeits und vereinsrechliche Aspekte des Sports Sponsoring, Schulthess Polygraphisher Verlag, Zurich,

Stallard Hayley; (1998), Bagehot on sponsorship, merchandising and endorsement, Chapter 7, Endorsement, London Sweet\&Maxwell,

Schaaf Phil, (2004), Sports, inc, 100 years of Sports Business, Prometheus Books, New York,

Stupp Howard, (1993), Broadcasting, International Sports sponsorship, Sports Marketing Europe, The Legal and Tax aspects, Kluver Law and Taxation Publishers, Deventer, Boston,

Vieweg Klaus,(1994), Sponsoring und Sportrecht, Sport nr. 1-2/94,

Verow Richard, Lawrence Clive, McCormick Peter, (1999), Sport, Business and the Law, Jordans,

\section{OSNOVNI ELEMENTI UGOVORA O SPONZORIRANJU U SPORTU}

Sponzorstvo predstavlja vrlo važni izvor financiranja velikog broja sportskih organizacija. Cilj ovog članka je analiza strukturalnih elemenata ugovora o sponzoriranju te imajući u vidu različite izvore iz komparativnog prava prijedlog ispravne definicije ugovora o sponziriranju. Uvid u strano zakonodavstvo nam pokazuje da nema države koja ima legalno oblikovani ugovor o sponzoriranju. Neka zakonodavstva reguliraju sponzorstvo neizravno koristeći opća pravila ugovornog prava ili pojedine elemente drugih ugovora koji već postoje i koje pravni sistemi već regfuliraju. Cilj je autora ovog teksta da zauzimajući stav o valjanosti argumentacije pojedinih autora dođu do vlastitog zaključka. U tom smislu ukazuju na Pravila o sponzorstvu ICC-a (Međunarodne trgovinske komore) koja mogu biti od koristi za različite sportske organizacije.

Ključne riječi: sponzoriranje, ugovor o sponzoriranju, Pravila Međunarodne trgovinske komore, elementi ugovora 